\title{
Evészavartünetek, problematikus evési magatartás egyes kamaszkori krónikus betegségekben
}

\author{
Cserép Melinda ${ }^{1,2}$ - Szumska Irena dr. ${ }^{1}$ \\ ${ }^{1}$ Semmelweis Egyetem, Általános Orvostudományi Kar, Magatartástudományi Intézet, Budapest \\ ${ }^{2}$ Semmelweis Egyetem, Általános Orvostudományi Kar, I. Gyermekgyógyászati Klinika, Budapest
}

\begin{abstract}
A táplálkozás iránti figyelmet igénylő krónikus betegségek (így a coeliakia, az l-es típusú diabetes és a gyulladásos bélbetegségek), valamint az evészavartünetek kapcsolata egyelőre kevéssé széleskörüen tanulmányozott terület serdülők körében. Az eddigi kutatási eredmények kiemelik a testkép- és evészavartünetek iránti magasabb kockázatot ezekben a betegségekben. Rizikótényező lehet az evési szokások megváltozása, a táplálkozásra irányuló fokozott figyelem és az ételekkel, valamint az elfogyasztásuk következményeivel kapcsolatos aggodalom. A korai felismerést nehezíti, hogy az evészavartünetek sokáig rejtve maradhatnak, és átfedést mutathatnak a krónikus betegség egyes tüneteivel (például testsúlyváltozás, hasmenés, hányás, hasfájás). A fennálló evészavar-érintettség gyengítheti a krónikus betegség hatékony terápiáját, súlyosbíthatja a szövődményeket, és növelheti a mortalitási rizikót. A tünetek korai felismerése és az adekvát terápia csak multidiszciplináris szemléletben és teammunkával, a szomatikus gondozás és a pszichoterápia összehangolásával lehet eredményes.
\end{abstract}

Orv Hetil. 2020; 161(44): 1872-1876.

Kulcsszavak: evészavar, serdülőkor, l-es típusú diabetes, gyulladásos bélbetegségek, coeliakia

\section{Disordered eating among adolescents with chronic illnesses}

\begin{abstract}
Disordered eating is not a well-understood phenomenon in diet-related chronic illnesses (e.g., celiac disease, type 1 diabetes, inflammatory bowel diseases) among adolescents. Previous research found a higher risk for eating disorders and negative body image among these patients. Following the prescribed or suggested dietary regime may lead to increased food awareness and become an eating disorder risk factor. Further risks may be the altered eating patterns, the fear from unknown food sources and its consequences. In many cases, eating disorder characteristics may be hidden and the symptoms of chronic illness (e.g., changes in weight, diarrhoea, vomiting, abdominal pain) and disordered eating can mimic each other. Disordered eating can worsen the effective therapy of physical illnesses and increase complications and mortality. Early diagnosis and adequate treatment can only be provided through multidisciplinary approach and teamwork.
\end{abstract}

Keywords: eating disorder, adolescent, type 1 diabetes, inflammatory bowel diseases, celiac disease

Cserép M, Szumska I. [Disordered eating among adolescents with chronic illnesses]. Orv Hetil. 2020; 161(44): 1872-1876.

(Beérkezett: 2020. április 24.; elfogadva: 2020. május 28.)

\section{Rövidítések}

BNO = Betegségek Nemzetközi Osztályozása; DEPS = $($ Diabetes Eating Problem Survey) diabetesspecifikus evészavarkérdőív; DSM-5 = (Diagnostic and Statistical Manual of Mental Disorders) Mentális Betegségek Diagnosztikai és Statisztikai
Kézikönyve; EAT-26 = az Evési Attitűdök Teszt rövidített változata; EDI-2 = (Eating Disorder Inventory) Evészavar Kérdö́v; $\mathrm{HbA}_{\mathrm{lc}}=$ hemoglobin-A-lc; IBD = (inflammatory bowel disease) gyulladásos bélbetegség 
A krónikus betegségek növekvő prevalenciája számos új kihívás elé állítja a témával foglalkozó szakembereket. Bármely betegség az élet valamennyi területét átható, az életminőséget befolyásoló nehézségeket okoz, melyek minden életkorban járhatnak adaptációs zavarokkal. A kamaszkorban fennálló krónikus betegség olyan meghatározó időszakra hat ki, melynek során az esetleges alultápláltság, a pubertás késése, a testi eltérések a fizikai fejlődésen túl az identitásfejlődést is markánsan érintik.

$\mathrm{Az}$ evészavarok (anorexia nervosa, bulimia nervosa, falászavar) súlyos, esetenként életet veszélyeztető pszichiátriai betegségek. Terápiájuk során szomatikus és pszichoterápiás intervenciók nagyon szoros, összehangolt munkát igénylő alkalmazása szükséges. A fóbb evészavarok élettartam-prevalenciája az Európában élő nők körében az alábbiak szerint alakul: az anorexia nervosáé $<1-4 \%$, a bulimia nervosáé $<1-2 \%$, a falászavaré $<1-4 \%$ [1, 2]. Szubklinikai evészavarról akkor beszélhetünk, ha az evészavartünetek (például fogyási szándék, a testtel való elégedetlenség) fennállnak, azonban nem merítik ki a BNO-10 vagy DSM-5 szerinti kritériumokat. Evészavartünet lehet számos olyan, evéshez kapcsolódó viselkedésforma, mely bizonyos gyakoriság és súlyosság esetén eléri a betegség szintjét, de enélkül is negatívan befolyásolja a személy emocionális és szociális életét, testi jóllétét. A kóros evési magatartás kategóriájába tartozik a túlzott diétázás, a kalóriamegvonás, a falás, a fogyás érdekében extrém módon végzett testmozgás, a hashajtók alkalmazása, a hányás. Serdülőkorú iskolások körében végzett vizsgálatok szerint a lányok közel felénél, a fiúk több mint negyedénél megjelenik a kóros evési magatartás $[3,4]$.

\section{A diétázás pszichés hatásai krónikus betegségekben}

$\mathrm{Az}$ egyes krónikus betegségek, állapotok (például 1-es típusú diabetes, coeliakia, gyulladásos bélbetegségek) diagnosztizálásakor a javasolt diétás elóírások alapjaiban változtathatják meg a korábbi evési magatartást. A diétázásra irányuló fokozott figyelem az evéssel, testtel kapcsolatban negatív viszonyulást idézhet elő, ami zavart evési magatartásba torkollhat. Az ellenállás megjelenése az étkezéssel kapcsolatos szabadság korlátozása miatt gyakori reakciónak tekinthető. A diéta nem megfelelő betartása fájdalmas vagy ijesztő testi tüneteket okozhat, így az evéshez és bizonyos ételek elfogyasztásához nemritkán félelem társulhat $[5,6]$.

Satherley és mtsai [7] egy olyan - kétutas - teoretikus modellt dolgoztak ki, mely segít megérteni, milyen folyamatok vezethetnek a diétázással járó betegségek esetén evészavarhoz. A szerzók egyrészt hangsúlyozzák, hogy azok, akik jelentős szorongást élnek meg ismeretlen hatásúnak vélt ételekkel kapcsolatban, hajlamosak túlbecsülni az egyes ennivalók betegségükre gyakorolt negatív következményeit. Jellemző rájuk, hogy kerülik az általuk nem kontrollálható ételek fogyasztását, ezáltal beszúkült az étkezési repertoárjuk. A modell másik része azon egyénekre vonatkozik, akik súlygyarapodást észlelnek az étrendi előírások betartását követően. A testsúly emelkedése a testtel való elégedetlenséget, fogyási szándékot, evészavartüneteket vonhat maga után.

A továbbiakban az l-es típusú diabetesnek, a gyulladásos bélbetegségeknek és a coeliakiának az evészavarokkal való kapcsolatára térünk ki, az eddigi fontosabb kutatási eredményeket összefoglalva.

\section{1-es típusú diabetes és evészavartünetek kamaszkorban}

Az l-es típusú diabetes az egyik leggyakoribb tartós betegség gyermekkorban. Incidenciája egyértelmú növekedést mutat - évente kb. 3\% körül - az elmúlt időszakban, s ez fiatalabb életkorban a legkifejezettebb $[8,9]$. Az inzulindependencia és a diétás előírások folyamatos önkontrollt, figyelmet igényelnek a gyermektől és a szülőktől egyaránt. A betegséggel járó számos változáshoz való alkalmazkodást a család rugalmassága nagymértékben befolyásolja. Az evésre és a szénhidrátbevitelre irányuló fokozott figyelem hajlamosító tényező az evészavartünetek vagy az evészavarok kialakulása szempontjából. A kamaszok sokszor nehezen élik meg, hogy a diagnózist megelőző fogyáshoz képest az inzulin beállítását követően súlygyarapodás következik be. Ez a testi változás az evészavarok szempontjából veszélyeztető faktor lehet. Természetesen bármely általános evészavartünet megjelenhet diabetesben érintett kamaszoknál, létezik azonban egy kimondottan erre a betegségre jellemző sajátos jelenség, az inzulinnal való manipuláció, mely purgáló viselkedésnek minősül [10-12]. Az evészavarban érintett vagy veszélyeztetett serdülők viszonylag gyakran alkalmazzák súlycsökkentésre és túlevés esetén a súlygyarapodás kivédésére az inzulin kihagyását vagy az előírt adag redukálását. Az életkor előrehaladtával az inzulin kihagyása gyakoribbá válik, fiatal felnőtt nők körében ennek gyakorisága a $40 \%$-ot is elérheti [13]. Az inzulinnal való manipuláció rövid távon ugyancsak nagyon veszélyes lehet, rendszeres alkalmazása egyértelműen növeli a mortalitást. Egy nők körében végzett utánkövetéses vizsgálat eredményei szerint azok között, akik a 11 éves követés elején kihagyták vagy aluldozírozták az inzulint, háromszorosra emelkedett a halálozás rizikója [13]. Az evészavar-érintettség sokáig rejtve maradhat, azonban mindig gondolni kell rá a diabetes egyensúlyban tartásának nehézségei, a kóros vércukorértékek és a kóros $\mathrm{HbA}_{\mathrm{lc}}$-érték esetén.

Pontos evészavarprevalencia-adatok egyelőre nincsenek l-es típusú diabetesben. Ennek egyrészt módszertani oka van, ugyanis a normálpopulációra kidolgozott, az evészavartüneteket mérő kérdőívek nem teljesen relevánsak cukorbetegség esetén. Ezen mérőeszközök a betegség sajátosságaiból adódó tényezőket (folyamatos figyelem az étkezésre, az inzulinnal való manipuláció lehetősége) nem veszik figyelembe. Diabetes Eating Problem Survey (DEPS) néven kidolgoztak egy 16 tételes, kimondottan 
diabetesspecifikus evészavarkérdőívet, melynek magyar adaptációja egyelőre nem áll rendelkezésre [14].

Young és mtsai [10] 1-es típusú diabetesszel élő kamaszok evészavartüneteit vizsgálták metaanalízisükben. Elemzésük alapján a szubklinikai és klinikai súlyosságú evészavarok is gyakrabban fordulnak elő diabeteses serdülőknél egészséges kortársaikhoz viszonyítva. Bár a normálpopulációra kidolgozott mérőeszközök nagyobb előfordulási arányt mérnek, diabetesspecifikus mérőeszközzel is magasabb az evészavartünetek előfordulása. A gyengébb glykaemiás kontroll és az evészavartünetek egyértelmüen összefüggést mutattak, nem csupán akkor, ha az evészavar diagnózisa felállítható volt, hanem egy-egy evészavartünet meglétekor is. Colton és munkacsoportja [15] vizsgálati eredményei már prepubertáskorban is igazolták, hogy a normáltól eltérő evési magatartás jegyei egyértelműen nagyobb arányban fordulnak elő 1 -es típusú diabetesben érintett gyerekeknél egészséges társaikhoz képest. Az evészavartünetekkel társult diabetes esetén hiányosabb betegségmenedzsment észlelhető, aminek következménye, hogy a cukorbetegség rövid vagy hosszú távú szövődményei nagyobb arányban fordulnak elő.

A klinikai munka során fontos, hogy az evészavartünetek szűrése megtörténjen, lehetőség szerint minden, diabetesben érintett kamasznál. Azoknál a serdülőknél, akiknél nehéz az étrend betartása, továbbá a diabeteskontrollvizsgálatok értékei aggasztóak, feltétlenül gondolni kell az evészavar lehetőségére is. Az evészavarral vagy annak tüneteivel társult diabetes esetén a teammunka nagyon szoros együttmúködésre kell, hogy épüljön a diabetológus szakorvos, a család-, valamint az egyéni terápiát végző szakemberek között [12].

\section{Coeliakia és evészavartünetek}

A coeliakia a lakosság kb. 1-1,4\%-át érintő, élethosszig tartó, immunmediált gasztroenterológiai kórkép. A genetikailag fogékony egyének esetében a kalászos gabonafélékben található glutén autoimmun reakciót vált ki, melynek során a vékonybélben található bolyhok elhalnak [16]. A coeliakia bármely életkorban előfordulhat [17]. Tünete lehet gyengeség, vérszegénység, krónikus hasmenés, haspuffadás, súly- és növekedésbeli elmaradás, valamint a pubertás késése. Egy-egy tünet sajátos esetekben mutathat átfedést evészavartünetekkel is. A coeliakia és az 1-es típusú diabetes társulhat egymással, ezért bármelyik diagnózisakor indokolt vizsgálni a másik autoimmun kórképet is. Egyetlen terápiás módszer létezik coeliakia esetén, az élethosszig tartó gluténmentes diéta. A lisztérzékenység diagnosztizálását követően a diéta betartásával a gastrointestinalis tünetek fokozatosan megszünnek, míg a hiányos együttmúködés fenntartja vagy súlyosbítja a tüneteket, így az adherencia nyomon követhető. Egészséges csoporthoz képest coeliakiában érintetteknél alacsonyabb szintű életminőség mutatkozik. Különösen nők számolnak be arról, hogy problémát jelent nekik a gluténmentes diétához kapcsolódó érzéseik kezelése, továb- bá jellemzó rájuk, hogy az ételek elkészítésekor fokozott kontrollra törekednek [6, 16, 17]. Társuló pszichés zavarként a kutatások a leggyakrabban hangulatzavarokat és szorongásos tüneteket írnak le [6, 18].

Egy izraeli kutatócsoport a coeliakia diagnózisát követően vizsgálta a gyerekek és családok étkezési szokásait. Eredményeik alapján az elhízás veszélye fokozottabb ebben az időszakban, s ez nem csupán a gyerekekre, hanem közeli hozzátartozóikra is jellemzőnek bizonyult. Egyelőre csak hipotézisek vannak a jelenség hátteréról, de elképzelhető, hogy a főzés, étkezés előtérbe kerülése a családban és az új élethelyzettel járó stressz kiváltotta fokozott evés is szerepet játszhat [19].

Karwantz és mtsai [20] coeliakiával élő kamaszoknál több evészavartünetet tapasztaltak az egészséges serdülőkhöz képest. Eredményeik alapján különösen a bulimiás tünetek gyakoribbak. A legtöbb esetben a coeliakia diagnózisa megelőzte az evészavartünetek megjelenését. Tokatly Latzer és mtsai [21] szintén lisztérzékeny kamaszokat vizsgáltak. A lányok 19\%-ánál, a fiúk 7\%-ánál tapasztaltak kóros evési magatartást az Evési Attitűdök Teszt rövidített változatát alkalmazva (EAT-26). A kutatócsoport az idősebb és túlsúlyos serdülők esetén nagyobb arányban mért 20-nál magasabb pontot a kérdőívben.

Míg diabetesben a már fentebb leírt, inzulinnal való manipuláció szélesebb körben vizsgált és egyértelmúen leírt jelenség, coeliakiában egyelőre csak esetleírásokban találkozhatunk azzal, hogy evészavarban érintett lisztérzékeny egyének testsúly-manipulálási szándékkal fogyasztanak glutént [22].

Egy olasz vizsgálatban coeliakiával frissen diagnosztizált felnőttek evéssel kapcsolatos, szorongásos és depressziós tüneteit tanulmányozták egészséges kontrollcsoporthoz viszonyítva [23]. Érdekes eredmény, hogy a coeliakiában érintettek nagyobb arányú szénhidrátbevitelről számoltak be, aminek alapján a szerzők feltételezik, hogy a lisztérzékenységre nagyobb genetikai hajlammal bíró egyéneket már a betegség megjelenése előtt fokozott szénhidrátfogyasztás jellemzi. Az EAT-26 kérdőívben egyértelmúen nagyobb arányban jelent meg az evéssel, testtel kapcsolatos aggódás coeliakiában érintetteknél az egészséges kontrollcsoporthoz képest. A magas pontszám az EAT-26 kérdőívben coeliakiás páciensek esetén nem korrelált a gastrointestinalis tünetek meglétével vagy intenzívebb szorongásos, depressziós tünetekkel. Az Evészavar Kérdőívben (EDI-2) több itemet illetően különbséget találtak a coeliakiások és az egészséges kontrollcsoport között (nőknél emelkedett volt a perfekcionizmus, a karcsúság iránti késztetés, az aszketizmus, az elégtelenség érzése, férfiaknál pedig az interoceptív tudatosság). A szerzők kiemelik, hogy egyelőre nem tudjuk pontosan, miért fordulnak elő egyes evészavartünetek gyakrabban a frissen diagnosztizált lisztérzékeny egyéneknél. Biológiai hátteret feltételeznek a megváltozott evési magatartás és a magasabb szénhidrátbevitel vonatkozásában, de a kérdőívekben megmutatkozó eltérésről a pszichés tüneteket illetően egyelőre keveset tudunk [23]. 
Mårild és mtsai [24] a coeliakia és az anorexia között kétirányú kapcsolatot írnak le. Bármely betegség jelenlétekor nagyobb az esély a másik probléma előfordulására. E mögött közös genetikai hátteret feltételeznek, melynek tisztázására további kutatások szükségesek.

\section{Gyulladásos bélbetegség és evészavartünetek}

A gyulladásos bélbetegség (inflammatory bowel disease, IBD) élethosszig tartó, relapsusok és remissziók váltakozásával járó immunmediált kórkép, mely a gastrointestinalis traktus súlyos fokú gyulladásával jár. Kialakulásában genetikai és környezeti tényezők egyaránt szerepet játszanak, de a betegség pontos etiológiája a mai napig nem ismert. A gyulladásos bélbetegségeknek két fó típusát ismerjük: a colitis ulcerosát és a Crohn-betegséget. Minden esetben olyan tartós problémáról van szó, amely jelentősen kihat az életminőségre, a testi fejlődésre, a társas kapcsolatokra, valamint az iskolai elömenetelre és a későbbi munkavállalásra. A betegség incidenciája az utóbbi években jelentős emelkedést mutat, prevalenciája - többek között Európa számos országában is - meghaladta a $0,3 \%$-ot [25]. Az IBD 15-25\%-a fordul elő gyermek- vagy serdülőkorban [26].

Egy svéd vizsgálatban a gyermekkori kezdetû IBD-vel diagnosztizált betegek és az illesztett kontrollcsoport pszichiátriai betegségeit követték nyomon, átlagosan 10 éven keresztül [27]. A kutatás további értékes részét képezte, hogy a hozzátartozók pszichiátriai betegségeit is beemelték a vizsgálatba. Kimutatták, hogy az IBD-s betegek között a pszichiátriai betegségek és az evészavarok kockázata nagyobb mértékü volt, mint a kontrollcsoportban. Mindegyik pszichiátriai zavar rizikója megháromszorozódott az IBD diagnózisát követő egy évben. Továbbá megállapították, hogy a korai kialakulás - a 6 éves kor alatt diagnosztizált IBD - ugyancsak megnövelte az evészavarok kockázatát. Ez utóbbi egyébként igaz a gyulladásos bélbetegség kapcsán sebészeti beavatkozást igénylő páciensekre is, továbbá azokra, akiknek hozzátartozói pszichiátriai betegek [27].

Az IBD-ben szenvedő betegek körében végzett vizsgálatokban nagy számban találtak az átlagostól eltérő evési mintázatot, a betegség aktivitásától függetlenül. Felnőtt betegek körében végzett kérdőíves vizsgálatok alapján a válaszadók közel 60\%-a úgy gondolta, hogy az evés szerepet játszik a relapsusokban. A páciensek több mint kétharmada nem fogyasztja kedvelt ételeit a visszaesés elkerülése érdekében. A betegek háromnegyede étvágycsökkenésről számol be, amikor a betegség aktív, továbbá az IBD-vel küzdők negyede úgy gondolja, hogy a diétázásnak a társas kapcsolataikra is kihatása van [28, 29].

Wardle és mtsai [30] felnőtt korú Crohn-betegeknél nagyobb arányban találtak evészavartüneteket, ezen belül is a leginkább falást és nagyobb fokú sóvárgást az ételek iránt. Az evészavartünetekkel rendelkező csoportban hangulatzavarok és szorongásos tünetek is nagyobb arányban fordultak elő. Prepubertás- és pubertáskorú IBD-sek szüleit vizsgálva Pituch-Zdanowska és mtsai [31] azt az eredményt kapták, hogy a szülők jelentős része aggódik az étkezés betegségre gyakorolt hatása miatt. A szülők beszámolói alapján a gyerekek 72\%-a nem fogyasztja (fogyaszthatja) kedvenc ételét az állapotrosszabbodás elkerülése céljából. A gastrointestinalis tünetek fölerősödésétől való félelem markáns lehet, és a restrikció irányába mozdíthatja el a betegek evési magatartását.

Ilzarbe és mtsai [32] evészavarral társult gyulladásos bélbetegségekkel foglalkozó 14 közleményt tekintettek át, melyek között a legnagyobb számban az anorexia nervosa és a Crohn-betegség komorbiditása fordult elő. A prognózis a két betegség együttes előfordulásakor kedvezőtlen, mert a gyulladásos bélbetegség gyógyszeres terápiáját az evészavarból adódóan gyakran visszautasítják a páciensek. Erre azért kerül sor, mert az evészavarral küzdő személy érdekelt a fogyásban, amit az IBD tüneteinek szándékos előidézésével el tud érni. Bár több tanulmány utal a gyulladásos bélbetegségek és az evészavarok lehetséges kapcsolatára, a pontos etiopatogenezis még nem ismert. A klinikai gyakorlatban a komorbiditás mielőbbi felismerése rendkívül fontos. Mivel a betegségekre jellemző tünetek egy része átfedést mutathat, nem mindig egyszerú a diagnózisalkotás, a multidiszciplináris teammunka a kezdetektől elengedhetetlen [34].

\section{Összefoglalás, kutatási kitekintés}

A diétával kísért krónikus betegségek, állapotok a kutatási eredmények szerint egyértelműen növelik az evészavartünetek kialakulásának rizikóját, amiben a diétázásra irányuló folyamatos figyelem meghatározó szerepet tölt be. A különféle evészavarokkal való társulás valószínüsége kb. kétszeresre tehető az átlagnépességhez viszonyítva. A kutatások eredményei szerint szorongásos, depressziós tünetek nagyobb előfordulása és alacsonyabb életminőség jellemzi az evészavartünetekben érintett, diétázásra kényszerülő, krónikus betegségben szenvedő kamaszokat. Egyelőre tisztázatlanok az ok-okozati öszszefüggések, bár úgy tünik, a betegség tüneteihez társuló félelmek az evészavartünetek megjelenésében hangsúlyos szerepet töltenek be. Betegségspecifikus evészavarkérdőívek kidolgozásával és alkalmazásával a diétázással járó krónikus betegségekhez társuló evészavarok prevalenciájáról pontosabb adatok állnának rendelkezésünkre. A rizikótényezők minél szélesebb körû ismerete a prevenció területére vezet el. Fontos lenne a jövőben, hogy a krónikus beteg, veszélyeztetett kamaszok szûrése az evészavarok irányában mielőbb megtörténjen. Ugyanakkor ajánlott - különösen a nem tipikus tüneteket mutató - evészavarban érintett serdülók vizsgálata a krónikus betegségek irányában is [33]. Az evészavarral, evészavartünetekkel szövődött krónikus betegségek hosszú távú kimeneteléról keveset tudunk, ennek jövőbeli kutatása kiemelten fontos, tekintettel a súlyos szövődményekre és a mortalitásra. 
Anyagi támogatás: A közlemény megírása anyagi támogatásban nem részesült.

Szerzői munkamegosztás: Cs. M.: A háttérirodalom öszszegyűjtése, a tanulmány megírása. Sz. I.: Szakértői részvétel a tanulmány végleges formájának kialakításában. A cikk végleges változatát mindkét szerző elolvasta és jóváhagyta.

Érdekeltségek: A szerzőknek nincsenek érdekeltségeik.

\section{Irodalom}

[1] Keski-Rahkonen A, Mustelin L. Epidemiology of eating disorders in Europe: prevalence, incidence, comorbidity, course, consequences, and risk factors. Curr Opin Psychiatry 2016; 29: 340-345.

[2] Szumska I, Túry F, Szabó P. New data concerning the epidemiology of eating disorders. In: Túry F, Pászthy B. (eds.) Eating disorders and body image disorders. [Az evészavarok epidemiológiájának újabb adatai. In: Túry F, Pászthy B. (szerk.) Evészavarok és testképzavarok.] Pro Die Kiadó, Budapest, 2008; pp. 109-120. [Hungarian]

[3] Neumark-Sztainer D, Wall M, Larson NI, et al. Dieting and disordered eating behaviors from adolescence to young adulthood: findings from a 10-year longitudinal study. J Am Diet Assoc. 2011; 111: 1004-1011.

[4] Sparti C, Santomauro D, Cruwys T, et al. Disordered eating among Australian adolescents: prevalence, functioning, and help received. Int J Eat Disord. 2019; 52: 246-254.

[5] Conviser JH, Fisher SD, McColley SA. Are children with chronic illnesses requiring dietary therapy at risk for disordered eating or eating disorders? A systematic review. Int J Eat Disord. 2018; 51: 187-213.

[6] Quick VM, Byrd-Bredbenner C, Neumark-Sztainer D. Chronic illness and disordered eating: a discussion of the literature. Adv Nutr. 2013; 4: 277-286.

[7] Satherley R, Howard R, Higgs S. Disordered eating practices in gastrointestinal disorders. Appetite 2015; 84: 240-250.

[8] Patterson CC, Karuranga S, Salpea P, et al. Worldwide estimates of incidence, prevalence and mortality of type 1 diabetes in children and adolescents: results from the International Diabetes Federation Diabetes Atlas, $9^{\text {th }}$ edition. Diabetes Res Clin Pract. 2019; 157: 107842.

[9] Maahs DM, West NA, Lawrence JM, et al. Epidemiology of type 1 diabetes. Endocrin Metab Clin North Am. 2010; 39: 481497.

[10] Young V, Eiser C, Johnson B, et al. Eating problems in adolescents with type 1 diabetes: a systematic review with meta-analysis. Diabet Med. 2013; 30: 189-198.

[11] Pinhas-Hamiel O, Hamiel U, Levy-Shraga Y. Eating disorders in adolescents with type 1 diabetes: challenges in diagnosis and treatment. World J Diabetes 2015; 6: 517-526.

[12] Hanlan ME, Griffith J, Patel N, et al. Eating disorders and disordered eating in type 1 diabetes: prevalence, screening, and treat ment options. Curr Diab Rep. 2013; 13: 909-916.

[13] Goebel-Fabbri AE, Fikkan J, Franko DL, et al. Insulin restriction and associated morbidity and mortality in women with type 1 diabetes. Diabetes Care 2008; 31: 415-419.

[14] Markowitz, JT, Butler DA, Volkening LK, et al. Brief screening tool for disordered eating in diabetes: internal consistency and external validity in a contemporary sample of pediatric patients with type 1 diabetes. Diabetes Care 2010; 33: 495-500.

[15] Colton P, Olmsted M, Daneman D, et al. Disturbed eating behavior and eating disorders in preteen and early teenage girls with type 1 diabetes: a case-controlled study. Diabetes Care 2004; 27: 1654-1659.

[16] Singh P, Arora A, Strand TA, et al. Global prevalence of celiac disease: systematic review and meta-analysis. Clin Gastroenterol Hepatol. 2018; 16: 823-836.e2.

[17] Fedor I, Zöld É, Barta Zs. The extraintestinal spectrum of gluten sensitivity. [A gluténérzékenység extraintestinalis spektruma.] Orv Hetil. 2019; 160: 1327-1334. [Hungarian]

[18] Arigo D, Anskis AM, Smyth JM. Psychiatric comorbidities in women with celiac disease. Chronic Illn. 2012; 8: 45-55.

[19] Levran N, Wilschanski M, Livovsky J, et al. Obesogenic habits among children and their families in response to initiation of gluten-free diet. Eur J Pediatr. 2018; 177: 859-866.

[20] Karwautz A, Wagner G, Berger G, et al. Eating pathology in adolescents with celiac disease. Psychosomatics 2008; 49: 399406.

[21] Tokatly Latzer IT, Lerner-Geva L, Stein D, et al. Disordered eating behaviors in adolescents with celiac disease. Eat Weight Disord. $2020 ; 25$ : 365-371.

[22] Leffler DA, Dennis M, Edwards George JB, et al. The interaction between eating disorders and celiac disease: an exploration of 10 cases. Eur J Gastroenterol Hepatol. 2007; 19: 251-255.

[23] Passananti V, Siniscalchi M, Zingone F, et al. Prevalence of eating disorders in adults with celiac disease. Gastroenterol Res Pract. 2013; 2013: 491657.

[24] Mårild K, Størdal K, Bulik CM, et al. Celiac disease and anorexia nervosa: a nationwide study. Pediatrics 2017; 139: e20164367.

[25] Ng SC, Shi HY, Hamidi N, et al. Worldwide incidence and prevalence of inflammatory bowel disease in the $21^{\text {st }}$ century: a systematic review of population-based studies. Lancet 2017; 390: 2769-2778.

[26] Veres G, Cseh Á, Müller KE. Transition or transfer: movement of children with chronic inflammatory bowel disease to adult care system. [Tranzíció vagy transzfer: a krónikus gyulladásos bélbetegségben szenvedő gyermekek átadása a felnőttellátásba.] Magy Belorv Arch. 2015; 68: 217-223. [Hungarian]

[27] Butwicka A, Olén O, Larsson H, et al. Association of childhoodonset inflammatory bowel disease with risk of psychiatric disorders and suicide attempt. JAMA Pediatr. 2019; 173: 969-978.

[28] Zallot C, Quilliot D, Chevaux JB, et al. Dietary beliefs and behavior among inflammatory bowel disease patients. Inflamm Bowel Dis. 2013; 19: 66-72.

[29] Limdi JK, Aggarwal D, McLaughlin, JT. Dietary practices and beliefs in patients with inflammatory bowel disease. Inflamm Bowel Dis. 2016; 22: 164-170.

[30] Wardle RA, Thapaliya G, Nowak A, et al. An examination of appetite and disordered eating in active Crohn's disease. J Crohns Colitis 2018; 12: 819-825.

[31] Pituch-Zdanowska A, Stawicka A, Jarocka-Cyrta E, et al. P346 Dietary practices and beliefs among parents of children with inflammatory bowel disease: preliminary results. J Crohns Colitis 2017; 11 (Suppl 1): S253.

[32] Ilzarbe L, Fàbrega M, Quintero R. Inflammatory bowel disease and eating disorders: a systematized review of comorbidity. J Psychosom Res. 2017; 102: 47-53.

[33] Avila JT, Park KT, Golden NH. Eating disorders in adolescents with chronic gastrointestinal and endocrine diseases. Lancet Child Adolesc Health 2019; 3: 181-189.

[34] Antal-Uram D, Harsányi L, Perczel-Forintos D. Low-intensity, evidence-based cognitive-behavioural therapy of a patient with Crohn's disease. [Az alacsony intenzitású, bizonyítottan hatékony kognitív viselkedésterápia Crohn-betegségben.] Orv Hetil. 2018; 159: 363-369. [Hungarian]

(Cserép Melinda,

Budapest, Bókay J. u. 53., 1083 e-mail: cserepmelinda@gmail.com)

A cikk a Creative Commons Attribution 4.0 International License (https://creativecommons.org/licenses/by/4.0/) feltételei szerint publikált Open Access közlemény. (SID_1) 